\title{
Analysis of Key Issues in The Frame-fixed Row-pattern Pile Cofferdam Construction of Binzhou Port
}

\author{
Xiaowen $\operatorname{Bian}^{1, a^{*}}$ and Tao $\mathrm{Yu}^{2, \mathrm{~b}}$ \\ ${ }^{1}$ Binzhou Polytechnic No.919, Binzhou, Shandong, China \\ ${ }^{2}$ Shandong gangtong Project Management Consulting Co., Ltd., Yantai, Shandong , China \\ a179042508@qq..com, b22751890@qq.com
}

Keywords: Binzhou port; The frame-fixed row-pattern pile cofferdam structure; Construction

\begin{abstract}
The cofferdam in the liquid bulk areas of Binzhou port haigang district used a new type of structure called the frame-fixed row-pattern pile cofferdam. It not only applies to the soft soil foundation of binzhou port, but also can be used as landing structure of pier in the late. However, the construction of this kind of structure has no more mature experience, and it is greatly influenced by the construction site environment of binzhou port. Therefore, the key problems and solutions to the construction of wall pile frame structure are analyzed.
\end{abstract}

\section{Introduction}

The frame-fixed row-pattern pile cofferdam structure is a new type of structure, which is suitable for the soft soil foundation of Binzhou port. It is similar to sheet pile structure, and combines the advantages of gravity structure and high pile structure. It has good integrity and high durability, and has strong applicability and comprehensive utilization. However, as the frame-fixed row-pattern pile cofferdam structure is a new type of structure, there will be some problems in the construction process. In order to ensure the effect of the future, the key problems in the construction must be analyzed and the solutions are put forward.

\section{Project Overview}

The construction of Cofferdam for the liquid bulk cargo area of Binzhou port is located in the liquid bulk operation area planned by Binzhou port, and 30 thousand tons of wharf have been built near the port area. This project belongs to the temporary cofferdam in the dredging area of the liquid bulk operation area. The cofferdam structure is designed according to the temporary engineering, and the structural safety grade is three. In the near future, it is used as the dredged mud area of the harbor basin and the channel, and it can be used as the shore connection structure of the high piled wharf.

\section{Key Points Analysis of Construction}

\section{Non Mature Construction Technology of the frame-fixed Row-Pattern Pile Cofferdam Structure}

New type of the frame-fixed row-pattern pile cofferdam structure is adopted in this project, prefabrication and shipment and installation framework are of great difficulty, no mature construction technology. the frame-fixed row-pattern pile cofferdam structure has been mainly used in Tianjin port. But its construction is greatly influenced by the special environment of the construction site. Therefore, when using this structure, Binzhou port must be combined with the on-site conditions for construction.

\section{The Planeness of the Frame Installation is the Key to the Construction}

The smoothness of the frame installation directly determines the successful implementation of the follow-up process. The framework is arranged on the wall of the pile beam, frame level, pile wall verticality cannot meet the requirements, but also easy to cause the touch pile; frame level is insufficient, cause difficulties and parapet cap beam construction. 


\section{Pipe Pile Setting is the Key Point of Control}

On the basis of Tianjin port, the slope pile is added to the wall pile frame structure cofferdam of Binzhou port to improve the ability of the structure to resist the horizontal force. The length of pipe pile is small, and the construction of inclined pile is more complicated. In order to avoid the piling, the angle of the pipe pile setting is the key point of control.

The Pressure of Cofferdam Closure is Larger

The project area encircled the surface area of about 2 million square meters, about $3 \mathrm{M}$ high tide and low tide when the water level difference, high and low tide in a large amount of water within the area required by the closure, closure and position of currents, in particular the closure section of the pressure, it must choose a good location of the final closure and closure of the appropriate length. To select the suitable time of closure, to ensure a successful closure dike.

\section{The Supply Strength of Sand and Stone is Great}

The construction and prefabrication and cofferdam construction require large quantities of sand and stone materials, while Binzhou area does not produce sand and stone. Therefore, we need to do well in the procurement and supply of stone materials, so as to ensure the continuity of construction.

\section{During the Construction of Embankment Settlement Control is the Key}

The foundation of Cofferdam for silt and silty clay, the construction of large ground subsidence, levee settlement displacement control needs through the construction always.

\section{Large Number of Ships and Great Disturbance in the Construction of Water}

This project mainly adopts water construction. During the construction period, there will be a large number of construction vessels in construction waters, such as piling boat, crane ship, pile carrier, traffic boat, measuring ship and frame transport ship.

The Construction Area is in a Semi Cover State, Which is Greatly Affected by Wind and Waves, and the Problem of Construction Safety is Outstanding.

In the construction area, the water depth is deep, the surrounding of the construction area is not covered, the wind wave is greatly influenced, and the safety problems in the construction period are particularly prominent.

\section{Construction Quality Control of Deep Water Filling Bag is Difficult}

The lower part of the slope structure, the section of the dam engineering deep groove depth, filling bag construction depth in $7 \mathrm{~m} \sim 14 \mathrm{~m}$, filling bag laying filling bags and pull to shop in the traditional charge while precipitation process can effectively control.

The Upper Frame Structure After the Completion of the Installation such as cap beam and Inclined Pile Cap, the Top Hat Beam, are in Need of Offshore Construction Site Concrete Pouring, Wind and Tidal Influence, the Procedure is tedious, the Construction Efficiency is Low.

\section{Analysis of Solutions}

\section{Based on the Existing Experience Tailored}

The combination of Tianjin port east building materials wharf wall pile frame structure construction experience and the actual situation of the project site, optimization and improvement of construction technology of Tianjin port wharf building materials, the formulation of overall water prefabrication, installation and adjustment of large crane ship, water hydraulic hammer hanging pile and other important technical solutions, in the implementation of the initial scheme. Strict implementation of typical construction, a comprehensive grasp of the construction parameters, the perfect solution for the new technology mature.

Controlling the Perpendicularity of the Frame by Controlling the Level of the Frame

When the frame is installed and installed, the exposed height of the frame before entering the water is very small, so the perpendicularity of the monitoring is very difficult. Therefore, the perpendicularity of the frame is controlled by controlling the horizontal level of the frame. Before the installation of the installation, the overall measurement of the installation area, found that the impact of the installation of shallow points, ahead of time clearance. At the same time, the offshore measurement platform is set up. 
After setting up the spreader, the height measuring pole is set at the four corners of the frame, and the measurement and control of the four corners of the frame is carried out by the offshore measuring platform, so as to ensure the bottom level of the frame and the top level of the frame. For the large deviation of the bottom level of the sitting bottom, lift it in time, and adjust the bottom elevation of the bottom to adjust the coarse sand to the insufficient place.

\section{Strict Control of Pile Driving Angle}

Set the sea measurement platform, process monitoring of pile verticality; set requirements for this project construction pile guide frame with pile verticality inserted pile, hammer and pile and the pile for a guarantee; optimization design, the use of plug-in pile feeder, avoid eccentricity of the piling.

\section{Select the Proper Position of the Closure, the Length of the Closure and the Time of the Closure}

Combined with the existing structure of the East breakwater, the closure construction located in a position near the intersection of new cofferdam and existing East breakwater, through hydraulic calculation, the final closure length (including $248 \mathrm{~m}$ and then the East breakwater length), so you can use the existing pavement structure of East breakwater to play a protective effect on the closure dike, dike protection project to reduce the amount of closure. Longkou section dike structure adopting riprap for closure. The closure during flood tide after the selection of a small spring tide is completed, the main equipment of ships two times according to the general layout of the number of the closure in accordance with three times the normal amount to prepare, with each post, personnel, to ensure a successful closure.

\section{Ensure the Supply of Sand and Stone}

Before the start of the construction of multiple sources of contact materials, do a good job in the procurement, transportation, storage of stone materials to ensure that the supply of stone supplies continuously. The water transport line is planned well, and the barge transportation of stone materials is organized with the progress of the project. Comprehensive comparison of quarries around Binzhou port area, Shandong and Laizhou, Jingtang Port existing sand quarry more sand, stone supply is relatively stable, my unit has been with the local quarry signed contract can ensure complete feeding, during construction material supply continue to stall.

\section{Strictly Control Loading Rate and Strengthen Field Monitoring}

The slope of embankment, strictly control the loading rate of construction, strengthen field monitoring. According to the design of loading diagram layered rubble, displacement of a certain number of arranged along the axis of the embankment settlement observation points, observation and monitoring to strengthen the construction process, beyond the design standard to immediately stop loading, take measures to adjust the loading rate. The frame structure reduces the base stress and reduces the settlement of the frame through the tensile properties of the geotextile. In addition, before installation, we installed $500 \mathrm{~g} / \mathrm{m} 2$ high strength geotextiles at the bottom of the frame to increase the area of the bottom of the frame. 2 test frameworks were used to summarize relevant experience, and pertinent measures were formulated according to the test results.

\section{Unified Arrangement and Coordination of Various Construction Facilities}

In order to ensure the safety of the ship, to avoid mutual interference, according to the unified arrangement of the whole construction unit owners of waters and coordination under the command of the sea water on the construction of temporary mooring facilities, warning signal and dangerous signal to make detailed arrangements to ensure the safety of construction. For all the ships on the ground, all the operators on the water are allowed to conduct the water operation license before construction, and stipulate their respective routes to avoid the chaos of water traffic and prevent the collision accidents.

\section{The Policy of "Safety First"}

Before the construction, all construction personnel shall make safety technical disclosure, identify potential safety hazards in the construction process, and put forward the avoidance measures for the corresponding hidden dangers, requiring all construction personnel to strictly abide by them. Regular safety inspection, timely discovery of problems, exposing problems, and supervision and improvement, do not leave hidden security risks. At the daily production scheduling meeting, we should summarize the safety problems of the day, so that all employees' safety awareness string is always stretched. When the 
wind and waves are large, all ships must enter the surrounding areas of the construction area and have shelter zones or shelter anchorages in the surrounding areas of the construction area.

\section{New Filling Bag Construction Technology}

The new process of water on the ship lay under water bag, filling the whole ship, laying on the water bag, wearing a bag of sand rib bag, similar laying process of soft mattress laying sinking bag, filling bag cuff in advance to connect the filling hose, sinking bag directly after water filling irrigation. In order to improve the construction quality of the new process, the construction effect and the construction parameters of the filling bag are adjusted in time after the completion of the construction.

\section{Reasonably Arrange the Construction of Each Procedure at Sea}

Cap beam and inclined pile cap due to the water level changes, the construction efficiency is affected by the tidal influence, the construction time of construction should be reasonable, to prevent the impact of rising water level of concrete construction quality; wave wall and top hat beam in the water level fluctuation zone, therefore affected by the tidal effect is smaller, should arrange the construction to streamline, accelerate the efficiency of construction.

\section{Conclusion}

The cause of the diesel exhaust temperature may be in many ways, but eventually, after all is not the "gas" is the "oil", as long as we take a realistic attitude, concrete analysis of concrete problems, take reasonable measures, diesel engine exhaust temperature of the problem can be solved. This paper adopts the method of fault tree analysis, will cause two kinds of single cylinder causes the high exhaust temperature is set to the middle event, fault judging method, the theoretical analysis and practical judgment of the rapid processing of fault events, save, save manpower, is conducive to improve the processing speed of the fault.

\section{References}

[1] Haiyuan Yao, Study on the structure of wall pile frame Wharf [J]. Tianjin University.2013.

[2] Xiaoyu Guan,Frame wall pile cofferdam structure stability and structure optimization[C], Tianjin University.2015.

[3] Jun He, Construction technology of cast-in-place cap beam with wall pile frame structure[J], China water transport,2016. 